\title{
Civil Concepts of Magzhan and Individuals Magzhan Praised in His Songs
}

\author{
Kultas Kurmanbay, Aigerim Yessirkepova, and Shynar Raysova
}

\begin{abstract}
This article is about civil concepts of Magzhan and Individuals Magzhan Praised in his songs. M.Zhumabayev aspired to freedom and was a member of Alash party who wished to make his country independent and free from Russian Tsardom regime. First of all, M.Zhumabayev was a great poet. Here the authors analyzed civil concepts of Magzhan through his poems. This article described how Magzhan was seeking freedom and independence for his country which was exposed in his compositions. He relied on the next Kazakh generation and wrote a poem titled "I Believe in the Young People". His XX century Alash dream was fulfilled at the end of XX century. Kazakh state is an independent state.
\end{abstract}

Index Terms-Kazakh literature, civil concepts, freedom, Tsardom system.

\section{INTRODUCTION}

Magzhan Zhumabayev was in born on 23 June in Northern Kazakhstan, presently Zhumabayev region, in the village named Magzhan. He started school at the age of four, graduated from madrasah in Kyzylzhar and completed his secondary education having mastered Arabic, Persian and Turkish languages. He was able to read Oriental literature in origin. In 1970 at the age of 17 he entered Madrasah-Galiya in Ufa. The famous Tatar writer Galymzhan Ibragimmov was his teacher. In 1912 his first book "Sholpan" was published in Kazan. In 1913-1917 he studied in teachers' seminary and in 1923-1927 in Moscow literature and arts institution under the supervision of Bryussov. In 1938 Soviet Union sentenced him to death penalty as "an enemy of the nation".

He introduced a range of innovations to Kazakh Literature, he had his own school at the genre of poetry. Second, he was a public figure quite dedicated to improving the future of Kazakh state who shared his ideas through mass-media at that time. XX century was a very hard period for Kazakh state. Even though the Soviet system was deemed to be democratic and assured to bring independence to its member countries, the policy it followed was considerably different. The poets, writers, public figures were seeking for greater political freedoms. The Soviet authorities sent them all to jail. Some, such as Magzhan Zhumabayev, were treated as the enemies of the state and shot down during 1937-1938.

\section{WhO IS MAGZHAN ZHUMABAYEV}

Magzhan is an enlightener-pedagogue, poet, writer,

Manuscript received December 22, 2015; revised February 28, 2015

The authors are with the Nazarbayev University, Kazakhstan (e-mail gkurmanbay@nu.edu.kz, ayessirkepova@nu.edu.kz, sh.rays@mail.ru). journalist, statesman and national patriot. He struggled against tsar and Soviet colonization politics and tried to preserve his nation as a true son of alash.

Who is Magzhan for me, and which of his words do I constantly repeat? "The nation without language is a nation that lost its language; the aim is not to be just a nation in the world, that kind of nation will not survive. The first condition to be a nation is to have a language. The lack of language use represents the slow disappearance of the nation. The place, history, everyday lives are clearly reflected in one nation's language. Kazakh peoples' unhurried style of life and patient character are shown in Kazakh language" [1].

The writer's civil concept was the thing that even the earlier Kazakh generation has been dreaming of. The primary advantage of the people of that time was their dedication to freedom compared to the people of the world today. For example, Kazakh khans Khaknazar, Kassymkhan, Abylaykhan were freedom fighters who defended Kazakhs from enemies and spoke only Kazakh to their generations. However, there was no way to do so during Magzhan's times, because Russian Tsardom system continued to apply in the same old way even during the Soviet times. Kazakhs were deprived from their language, religion, set of mind, those who could neither read nor speak any Russian were treated as illiterate and alienated. This prompted the poet to start the public education process and release his own book called "The Pegagogics".

Where do the sources of Magzhan Zhumabayev's creativity come from? They come from Oriental classical literature, the history of Turkic nations, customs and traditions of Kazakh nation, language, oral literature and arts. Magzhan is a genuine representative of this world.

Why is Magzhan eager to write in historical themes? The reason is Kazakh people did not do anything in their history to be embarrassed by mankind, there were no invasions and there was no humiliation. Kazakh nation is a nation which is tolerant, merciful, and hospitable and loves his country and is able to protect it and considers an honour higher than a life. They possess a vast land, which is rich with resources and this is an independent country which loves freedom. Magzhan was a poet who was against Russian Tsar and Soviet system that took away a land, stole its resources and mercilessly killed the citizens of such country.

What do the works of Magzhan offer to independent generation of Kazakh country? There is no worth for students and Magzhan in just teaching his works, plainly memorizing and praising his works. Instead of this it is better to ask the following questions to the youth of independent country "Why did Magzhan to be an independent country? What did he do for that?" 
One century ago in his poem "I believe the youth" he addressed to Kazakh youth: "Young people, follow the example of your brave brothers who devoted their lives to the service of Alash way. Think of the country which lost its land and suffers for two centuries. Think of the country that considers a day as a night, a relative as an enemy, benefit as harm and is ready to get its political rights" [2]. Although one century passed, it is still actual problems for today's youth.

The most distinctive peculiarity of works of poet Magzhan is his patriotic spirit. The poet expressed his objection to political state in Kazakh land in the beginning of XXth century by his poems. He felt with his heart that any kind of Russian predominance was a great sorrow for Kazakhs. He glorified ancient independence and says "Day" for the past and "night period" for the present.

The time reaches the next generation with its great personalities through chronicles. At the age of 20 Magzhan Zhumabayev wrote a poem "The past day". That song entered to the collection of Kazakh poets "Sizzing"/"Yzyng" as a poem entitled "The past day of Kazakhs" in 1913. The second updated version was published in Kazan collection in 1922. The names of places, names of historical personalities, their way of ruling the country, their justice and honesty and the purity of relationship between people take the reader to this wonderful world and inspires them. Kazakhstan's five rivers as five continents of the world: Volga, Ural, Syr Darya, Irtysh, Zhetisu regions are called Saryarka. The son who inhabits its place has a name of valorous Alash Hero. The poem is started this way.

Volga, Ural, Syr Darya, the known waters to the people. Sweet, delicious multi- channeled long Irtysh and Zhetisu. This region of five waters is called the place Saryarka, the son who is raised here is named "Valorous Alash Hero" [3].

This is a map of Kazakhstan written by this song. So what is the life style of people who live here?

Wandering freely everywhere, eating the grass desired. The place is rich with pristine forests, and vast clear lakes... The generous relatives, the poor don't have worries-if necessary they can catch a horse and ride it with no permission. No matter stranger or a relative, everyone is offered a meal. A kind hostess will give a kumiss in a big bowl [3].

This is Kazakh tradition, Kazakh image. This was Kazakh people who were generous not only by their food but also were close to everybody. They possessed their land and livestock. The relatives help each other, they don't upset one another and always had good relationships. The poet expresses this in this way: "The calm vast land, as though a soul enters".

It is true that there were arguments as well. In that case they came to the judge for reconciliation. From ancient times Kazakh people had the law of steppes, and people called it; "The straight road of Kassym", "The old road of Yessim". This was the road followed by the judge, the road of justice. The poet glorifies this wonderful national tradition. He praises the historical personalities who ruled the country. These personalities are Khaknazar khan, Abylai khan, the heroes Kabanbai, Bogenbai and Nauryzbai, wrestlers Zhanibek, Shozhe, Zhanak and Birzhan. Their heroism, government and arts are anthemed in the poems. He glorifies the old days of Kazakhs.
If I think of old times, if I contemplate about life, their beauty and wealth in past days of Kazakhs, appear in front of my eyes...Your strength is weakened, you walk on foot without riding. The ignorance is waiting to conquer you the whole.

Holding its sword, [3] - are the lines from a poem illustrate the fate of Kazakh country invaded by Russian empire in the beginning of the 20th century. The country which is taken away its beauty and wealth is not a free country, if it opens its mouth and shows opposition the enemy is ready to kill him by his sword. It is known by everybody that this "sword" killed a lot of sons of Kazakh nation. The poet who feels sorry for his nation at the end of the poem says these lines with his loving heart:

My lion, my falcon, my tireless, relentless jumper, raise your head and stand up! That day is over, this night is going to finish, don't grieve thinking about the past... The time is fox, be the hunter, it is time to rejoice, [3].

It is true that if the person who wants to len Kazakh history will learn a lot if he thoroughly reads this poem of poet Magzhan.

The historical personalities of "Past days" are Khaknazar, Abylai khan, heroes Kabanbai Batyr, Bogenbai Batyr, Kazybekk bi, poet Shozhe, poet Orynbai and Birzhan Sal.

One more work of Magzhan Zhumabayev which is close to our theme is a poem "Turkistan". Turkistan is considered to be a holy and sacred place for Muslim people. It might be because of the history of Turkistan. In 19 lines of 25-line poem "Turkistan" the author describes the history of Turan.

The ancient ruler Afrasiyab who ruled the whole Turan. From the ancient times it is not just the land, you will know Turan, if you learn the history [3].

The Great Yerr Tonga is a historical personality who lived in 1-2 century BC. The Great Er Tonga is a hero and lord of Turan who protected it. It is written in ancient Orkhon writings about the Great Er Tonga. Abu Raikhan, al-Biruni, Makhmut Kashagari, Muhammed Haidar Duati, Khamza Isfahani, Rashid ad-Din and others mentioned the Great Yer Tonga and his literary image in epics. All of them described a main character of the epics the Great Yer Tonga as a statesman. They showed the Great Yer Tonga as a talented general especially in the war between Turan and Iran.

Zhussip Balasagun in his epic "Kutty Bilik" devoted one part to Great Yer Tonga and called it "About the kind deeds and traits to be praised". The pages from [4] 101 to 102 of "Kutty Bilik" narrate completely about the good deeds of the Great Yerr Tonga, his aristocracy, wisdom, the way of ruling Turan, his talent to be a general, his protective attitude to people, his generosity and other features of character [5].

There were judges in Turan like Taragai, he had a brave son named Temir. He spread the fire to the lands as Temirlan, and was like a bright lightening in the sky.

I do not praise Turan in vain, people know about Turan without me. There were no people as Ulykbek, who talked to starts and Moon in the sky [3].

Amir Temir, born in 1336 in Turkistan (died in 18.02.1405 in Samarkand) was a military leader and statesman. The son of the judge from Barlas tribe. Temir was an ancestor such well-known personalities as a scholar Ulykbek (1394-1449) and a founder of Mogul empire Babur (1483-1530) [7]. 
Pure blood - sacred turkic blood, ibn-Sina Abugali belongs to this blood. He possessed the mysterious wisdom, has been another man born like him?

Who did not like the Turkic music, the nine-string dombyra of Farabi! When he played in ninety different ways, who did not hide the tears in eyes [3]?

Abuali ibn Sina is a scholar, philosopher and astronomer. His full name is Abu Ali Husein ibn Abdallah ibn Sina and known in Europe as Avicenna. Ibn Sina left a valuable hearitage: if we look at ancient materials he wrote about 456 works, but only 240 of his books reached our times, these works are in the sphere of philosophy, geology, astronomy and other fields of science. Ibn Sina gained his fame as being a doctor, scientist and pharmacist. He lived only 57 years (980-1037), but his life and his talent became a legend to nowadays [8].

Abu Nasyr Al-Farabi Abu Nasyr Muhammad ibn Tarhan ibn Uzlag al-Farabi (870-950) was a thinker, philosopher, sociologist, mathematician, physicist, astronomer, biologist, linguist and investigated music [8].

In the last lines of the poem "Turkistan" the period when Great Turan was collapsed is described as: "When many Turks argued for the land, was not the paternal land left for Kazakhs?" and mentions the Kazakh khanate that stayed as a fatherland for all Turkic nations.

The straight way of Kassym khan of Kazakhs, he ruled the vast land of Turan. Nazar is a just khan, the way of Yessim khan is ready for Alash.

The wise khan Tauke, Gathered a convention on Kultobe. This Turan land is a territory of Alash, the story of Alash comes from Turan.

The calmness was found in the land of Turan by the lion of Alash - Abylai...Do not separate Turan from Sary arka, Turkistan was Kaaba for six Alash. The hero of old times brave Kene, lies in the land of Turan embracing it [3].

The reason why Magzhan did not name the real founders of Kazakh khanate but referred as "The straight way of Kassym khan of Kazakhs" is in the fact that in the period of that khan Kazakh khanate became known as a strong country to other countries. The first historian of Kazakh nation Muhammed Khaidar Dulati in his work "Tarih-i Rashidid" writes about Kassym khan: "He ruled Deshti Kypshak. The number of his soldiers was more that thousands. There was no greater khan like him in this land after Zhoshy khan" [6]. The poet mentions the personalities he mentions in "The past days" in this poem as well. He writes about Khaknazar as "The just khan as Nazardayin". In this poem he also mentions one of the khans who contributed to the development of the country Yessym khan as "The way of Yessim khan is ready for Alash" and reminds of old way of Yessim khan. Tne next epoche of Kazakh khanate is a period of ruling of Tauke khan. The poet writes about "Zhety Zhargy" prepared at the time of Tauke khan, "Board of Judges" with help of which people came to agreement with government, convention on Kultobe where three hordes discussed important issues of the state and thanks to wise strategy of Tauke khan the country lived in peace for twenty years. The poet writes that is all because of the wisdom of Tauke khan. Magzhan glorifies Abylai khan with the same praise. The poet appreciates him and says "The lion of Alash Abylai.". He writes about the hard times at the period of
Abylai khan when Russian empire pressed from the north and Tsin empire pressed from the east, and how he managed to resist Jungar invasions and united all nation and defeated enemy.

Therefore the poet glorifies in his two poems the bravery and pride of khans such as Kassym, Khaknazar, Yessym, Tauke and Abylai who ruled Kazakh khanate at different times and raised its authority.

Despite of the fact that the poet was unfairly condemned because he glorified the past days, his main ambition was to found independent Alash autonomy. The way to gather people under one national ideology was to write about the bravery of khans who ruled Turan and preserved its independence.

The poem of Magzhan Zhumabayev "Batyr Bayan" is a historical poem. The poem was published in the journal "Sholpan" in 1923. The doctor of philological sciences, professor R. Nurgaliyev says that the poem of Magzhan Zhumabayev "Batyr Bayan" "is influenced by Shokan Ualikhanov's work "The historical myths about batyrs of 18th century" where he writes about Abylai and Bayan. Because the facts from Shokan's books are mentioned there too" [9].

The plot of the poem consists of two parts. The first part is about how Bayan invades Kalmyk country, catches the beautiful girl from Kalmyks, fell in love with her and the second part about Abylai and batyrs around him.

In two analyzed poems the poet Magzhan writes about his psychological state and past life of Kazakh people, whereas in the poem "Batyr Bayan" by its plot he writes about the history of that period, the actions, feelings and emotions of characters of that time.

The reason of appearance of this work lies in the desire of the poet to gain independence from colonization. It is very difficult to describe the hardships Kazakh country experienced in the beginning of the 20th century. At that time the poet again goes through the pages of history and writes the following work. "My heart, I am sad for hurt, Treacherous life is a torture for a person... As crafty life without interest tired me, I thoroughly looked at past" [3]

The event takes place in Kokshetau, Burabai. The poet perfectly illustartes the nature of Kokshe. We will not discuss the poet's talent of illustration as it is not related to our research. The focus of our research is historical personalities and kazakh batyrs. In this poem the names of seventeen batyrs are mentioned apart from Abylai khan.

The poet glorifies the distinctive feature of Abylai which is to protect Alash. And he makes vivid the worth of Bayan by the words of Abylai... The batyr who run out of patience, Abylai told to the judges that he would not start out if Bayan does not come... The people who gathered near Abylai khan were famous generals Kanzhygaly Bogenbai, Koshkaruly Zhanibek, and zhyraus such as Bukar and Tatikara. We think that there are two reasons to wait for Batyr Bayan. The first reason is that Bayan is described in the poem by the words of Abylai as a "broadsword", "strong steel" and respected by Abylai khan because he was very brave and scared the enemies. The second reason is his character which is not fitted to the famous strict temper of Abylai, the khan did not like people who flattered him and respected men who were able to say what they meant directly without fear. In the poem the 
khan feels the reason why Bayan was late, and tolerates his wish not to ask the reason and forgives his insolence to object the khan.

We can notice the following traits of the character of Abylai in the episode where he meets Bayan: first of all his patience and tolerance: Despite being the khan he says noting to Bayan for being late and forgives him; secondly, mutual respect with his soldiers because he did not only forgive him but he gives him a place near him and expresses great respect.

The vivid situation where we see the deep image of Abylai is how he reacts to the desire of Kalmyk ambassadors. He positively accepts Kalmyks' suggestion and refuses to kill the soldier, makes a mistake and Bayan tells khan's mistake in to his face.

In the end of the poem batyr Bayan with his friends starts a fight with enemies and dies because the powers were not equal, Abylai who sees it sends soldiers to help Bayan, and kalmyks "Because they were afraid of Abylai, they moved to China the next morning" and poem finishes this way.

In this poem not only the historical personality of Abylai but also his literary image is revealed. It is all thanks to talent of the poet.

\section{CONCLUSION}

It is evident that the Kazakh nation which became independent only 24 years ago needs a material wealth, an economic development to obtain true independence. Moreover, it is even more necessary to get rid of the subordination psychology which is the result of the Russification policy of alienating traditions, language and religion over 70 years by Soviet government, and 250 years by Russia. Kazakhstan (and other 15 republics) was dependent from Russia both from economic side and from the side of science and education. Soviet government educated Kazakhstan, which was the ninth biggest country in the world with rich resources, as the nation which was illiterate before the Soviet times. In 1937-1954 years talented and educated representatives of Kazakh nation were sanctioned and sentenced to death. As a result, Kazakh nation was left without the spiritual leader. The mentality of the nation which saw the cruel punishment had changed. People lost trust in each other.

Kazakh nation which became independent from the centralized Russian governance since 1991 and started to get back to its spiritual, historical values. There was an opportunity to educate Kazakh generation with independent educational content, standards and programs. With this purpose, books, educational standards, concepts of national education have appeared. The most suffering subjects before the independence were: Kazakh language, Kazakh literature, Kazakh history, Kazakh geography. On the contrary, Russian history and literature, geography were taught well. And now educational content of national subjects were redesigned. Speaking about our research objective which is Kazakh literature, the works of the authors who were recognized as nationalists during Soviet times in 1938, were implemented into the program of the schools and higher education institutions. Novels, tales, poems, lyrical songs of the poets and writers who dreamed about the independence of the nation at the beginning of the XXth century, and who tried to wake up the nation and advocated the need for freedom with the help of their works, were implemented into the educational content considering the age differences of pupils. One of those poets, who was recognized for his poetic talent already at that times, was Magzhan Zhumabayev, whose works are educating Kazakh youth to love the country, be patriots, and humanists. The poems and songs of the abovementioned poet has become one of the favorite works of students nowadays.

The books of Magzhan Zhumabayev are being published a lot. Republican journal named "Magzhan" has been being published since 2014. The documentary film "Tragedy of Magzhan" has also appeared. Republican contests on reading Magzhan's songs is held annually in the city of Pavlodar.

The appearance of the monographic works of the scientists whose research objective is the works of the poet has increased the interest of readers for the world of Magzhan.

There is a big chain of historical personalities in the works of Magzhan. We could not find it possible to mention all these personalities in one report. The poet's ambition to preserve historical personalities in the memory of the generations is caused by his faith in the future of Kazakh country. The historical personalities glorified in the works of poet are the people who preserved the independence of Kazakh country, and with no doubt the spiritual pillar in the idea of the President to be an Eternal country.

\section{REFERENCES}

[1] M. Zhumabayev, Pedagogika, Tashkent, pp. 65-68, 1922.

[2] M. Zhumabayev, Olengder, Almaty: Zhazushy, pp. 33-39, 2005.

[3] M. Zhumabayev, Sui, Zhan Saulem Poems, Almaty: Atamura, pp. 36-160, 2002.

[4] Z. Balasagun, Kutadgu Bilik, Turkistan, pp. 541-542, 2004.

[5] M. H. Dulati, Tarikh-i-Rashidi, Almaty: Turan, pp. 616-618, 2003.

[6] Y. Tonga. Encyclopedia in Kazakh language. [Online]. Available: kk.wikipedia.org/wiki/Yer-tonga

[7] Otyrar, Online Encyclopedia, Almaty: Arys, pp. 17-19, 2005

[8] M. Zhumabayev. Encyclopedia in Kazakh language. [Online] Available: http://www.kk.wikipedia.org/wiki/Magzhan_Zhumabay

[9] R. Nurgaliyev, Pure Feeling, High Common Sense, Almaty: Gylym, vol. 2, pp. 491-502, 1992.

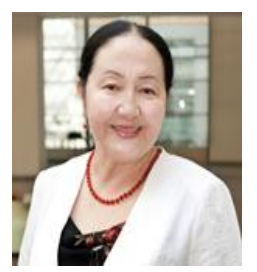

Kurmanbay Kultas was born in Taraz, Kazakhstan. She is a doctor of pedagogical science, professor at School of Humanities and Social Sciences, Chair of Kazakh Language, Literature and Culture Department, School of Humanities and Social Sciences at Nazarbayev University, Kazakhstan.

In 1997, Kultas Kurmanbay received the degree of candidate of pedagogical sciences. The topic of her dissertation was "Kazakh Literature Lessons in School and the Formation of Caring Attitudes toward Nature among Pupils."

In 2010, she received the degree of doctor of pedagogical sciences on the topic of "Scientific and Pedagocical Principles for Humanizing the Content of General Secondary Education."

Kultas Kurmanbay has received the following awards: She is a laureate of the "Award Named after I. Altynsarin". She received the award of "The Best High School Teacher" in 2008. She has an award for the excellent achievements in the educational system of the Republic of Kazakhstan.

Kultas Kurmanbay is an author of more than 100 articles, 3 monographs, 8 textbooks, 20 study guides and reading books. Her favorite activities are reading, writing books, and teaching. Indented around it. The photograph is placed at the top left of the biography. Personal hobbies will be deleted from the biography. 


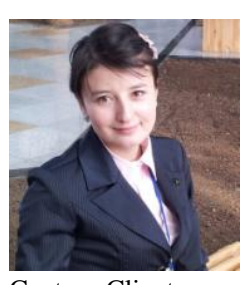

Aigerim Yessirkepova was born in Shymkent, Kazakhstan. She holds a master of arts degree (Eurasian National University after L. Gumilev, Astana, Kazakhstan) and bachelor's degree in Kazakh philology, Faculty of Philology, Kazakh National University named after Al-Farabi, Almaty, Kazakhstan. From 2006 to 2008 she worked as a

Kazakh language teacher at Language Learning Center «Client», as a journalist and interpreter in Nachnem s Ponedelnika and as an editor at Social Fund Wikibilim. /Wikipedia/ Currently: Teacher at Nazarbayev University, at the Department of Kazakh Language, Literature

\section{and Culture.}

She is currently developing Kazakh - English phrasebook. She has participated in a number of national and international conferences on applied linguistics and in research projects such as the contribution of the Turkic World into the world Civilization Kazakh National University named after Al-Farabi, Almaty, Oktober 17, 2012. And effective methods and stages of grammar of studying in language teaching Prague, Czech Republic on May 16, 2013. Her area of research is Language learning and teaching, more specifically in the fields of Kazakh Language. She has published a number of research papers on language learning and teaching. 